\title{
Suggestions Regarding Veterinary Education Based on the National Standard Veterinaran Qualification Examination in China
}

\author{
Jianfa Wang, Xu Zhang, Donghua Guo, Jingru Guo, Rui Wu, Dongbo Sun* \\ College of Animal Science and Veterinary Medicine, Heilongjiang Bayi Agricultural University, Daqing, China \\ Email: ${ }^{*}$ dongbosun@126.com
}

Received 4 May 2015; accepted 4 July 2015; published 7 July 2015

Copyright (C) 2015 by authors and Scientific Research Publishing Inc.

This work is licensed under the Creative Commons Attribution International License (CC BY). http://creativecommons.org/licenses/by/4.0/

CC) (i) Open Access

\begin{abstract}
The national standard veterinarian qualification examination, which starts running in 2010 in China, is a major reform about management system of veterinary practitioners. The veterinary education is subjected to a new requirement due to the performance of the national standard veterinarian qualification examination. In the current review, the overview of veterinary education in Heilongjiang Bayi Agricultural University (HBAU) was described, and some positive suggestions were provided about the veterinary clinical diagnostics course, which is an important compulsory course undertaken by undergraduate, based on the national standard veterinarian qualification examination in China.
\end{abstract}

\section{Keywords}

Veterinary Medicine, Veterinarian Qualification Examination, Veterinary Education, Veterinary Clinical Diagnostics

\section{Introduction}

In order to standardize the requirements for individuals who want to practice veterinary medicine, a pilot exam was run in five provinces and municipalities in 2009 in China, and then the national standard veterinarian qualification examination was held once a year starting in 2010 (Wu \& Weng, 2009; Wang, 2013). The national standard veterinarian qualification examination is an entry-level standard in the veterinary medicine profession (You et al., 2010). If you plan to practice veterinary medicine, not only do you need to get veterinary medicine

*Corresponding author.

How to cite this paper: Wang, J. F., Zhang, X., Guo, D. H., Guo, J. R., Wu, R., \& Sun, D. B. (2015). Suggestions Regarding Veterinary Education Based on the National Standard Veterinaran Qualification Examination in China. Creative Education, 6, 1270-1273. http://dx.doi.org/10.4236/ce.2015.612126 
or related degrees, you also must pass the national standard veterinarian qualification examination. The national standard veterinarian qualification examination is divided into two categories: the veterinary medicine and the aquatic animals. In the category of the veterinary medicine, the national standard veterinarian qualification examination includes comprehensive knowledge exam and clinical skill exam, covering all veterinary medicine courses taught in China (available at the online website of the Chinese Veterinary Medical Association http://www.cvma.org.cn/index.aspx). At present, the veterinary medicine-associated institutions in China pay high attention to the national standard veterinarian qualification examination (Wen, 2010). In the future, the number of students, participating in the veterinarian examination and their success rate, will become an important factor to evaluate the quality of education in veterinary schools.

\section{Veterinary Education of Heilongjiang Bayi Agricultural University}

Heilongjiang Bayi Agricultural University (HBAU) was first established in Mishan city, Heilongjiang province, northeast China during 1958 and it moved to Daqing city in Heilongjiang province during 2003. The HBAU has 13 colleges, 44 undergraduate's programs, 37 master's programs, six doctoral tracks, and four specialized master's programs related to agriculture. There are also three post-doctoral scientific research workstations in the HBAU (available at the online website http://www1.hlau.cn/english/). The College of Animal Science and Veterinary Medicine is one of the leading major in the HBAU, which focuses on veterinary education and animal science education. In Table 1, the veterinary medicine education profile is showed during the past six years in the HBAU. The enrollment rates of graduate students ranged from $17.02 \%$ to $33.33 \%$ during $2007-2012$, while the level of direct employment of undergraduate students ranged from $66.67 \%$ to $82.98 \%$ in the HBAU. These data suggest that one of the main aims of veterinary medicine education at HBAU is to provide practical veterinarian. After the national standard veterinarian qualification examination run in 2010, the veterinary education of the HBAU has been faced with new demands and challenges because most of students need to pass the examination in China (Wen, 2010; Li et al., 2011).

\section{Veterinary Clinical Diagnostics Teaching in the HBAU}

The veterinary medicine courses of the HBAU are showed in Table 2. In the HBAU, before applying for their bachelor's degrees, students who are majoring in veterinary medicine need to achieve 165 credits, in which 37.5 credits from general compulsory courses, 10 credits from general elective courses, 20 credits from general basic courses, 16 credits from basic professional courses, 32.5 credits from professional compulsory courses, 18 credits from professional elective courses, and 31 credits from professional elective compulsory practical courses. The veterinary clinical diagnostics (VCD) is an introductory course in all veterinary medicine courses, consisting of 46 credit hours of theoretical teaching, and 10 credit hours of practical teaching. The VCD course serves as a bridge between professional courses and basic courses in veterinary medicine (Sun et al., 2009). Meanwhile, the VCD course also possesses a major proportion in the national standard veterinarian qualification examination. These characteristics make the VCD course a suitable target for the exploration of teaching reform for high-pass rates in the national standard veterinarian qualification examination.

\section{Suggestions Related to VCD Teaching}

\subsection{Syllabus of the VCD Course}

The syllabus is an outline of the course, involving in the teaching aims, teaching content, teaching methods,

\begin{tabular}{cccc}
\multicolumn{4}{c}{ Table 1. Undergraduate students profile of veterinary medicine of HBAU in the past six years. } \\
\hline Years & $\begin{array}{c}\text { Total numbers of undergraduate } \\
\text { students }\end{array}$ & $\begin{array}{c}\text { Numbers and percentages of } \\
\text { employment }\end{array}$ & $\begin{array}{c}\text { Numbers and percentages of } \\
\text { graduate students }\end{array}$ \\
\hline 2007 & 118 & $81 / 68.64 \%$ & $37 / 31.36 \%$ \\
2008 & 147 & $115 / 78.23 \%$ & $32 / 21.77 \%$ \\
2009 & 77 & $63 / 81.82 \%$ & $14 / 18.18 \%$ \\
2010 & 141 & $117 / 82.98 \%$ & $24 / 17.02 \%$ \\
2011 & 130 & $90 / 69.23 \%$ & $40 / 30.77 \%$ \\
2012 & 129 & $86 / 66.67 \%$ & $43 / 33.33 \%$ \\
\hline
\end{tabular}


Table 2. Veterinary medicine course profile in HBAU.

\begin{tabular}{|c|c|}
\hline Course types & Course names and credit values \\
\hline General compulsory courses & $\begin{array}{l}\text { Essentials of China Modern and Contemporary History (2.0), Cultivation of Morals and Fundamentals } \\
\text { of Law (3.0), Marxist Fundamentals (3.0), Outline to Mao Zedong Thoughts and the Chinese } \\
\text { Characteristic Socialism Theory System (6.0), College Foreign Language (14), Physical Education } \\
\text { (4.0), Foundation of University Computer (2.5), College Student Profession \& Development Planning } \\
\text { (1.0), Graduate Employment Guidance (1.0), Situation and Policy (1.0) }\end{array}$ \\
\hline General elective courses & $\begin{array}{l}\text { Generate Your Business Idea (1.0), Start Your Business (3.5), Mental Health Guide (1.0), Cultural } \\
\text { Elective Courses for (7.0) }\end{array}$ \\
\hline General basic courses & $\begin{array}{l}\text { Higher Mathematics (5.0), Probability (1.5), Inorganic Chemistry (3.0), Organic Chemistry (3.0), } \\
\text { Analytical Chemistry (2.0), Chemistry Experiment (2.5), College Physics (2.5), College Physics } \\
\text { Experiment (0.5) }\end{array}$ \\
\hline Professional basic courses & $\begin{array}{l}\text { Zoology (2.5), Animal Anatomy (3.0), Animal Tissues and Embryology (2.5), Animal Biochemistry } \\
\text { (4.0), Animal Physiology (4.0) }\end{array}$ \\
\hline $\begin{array}{l}\text { Professional compulsory } \\
\text { courses }\end{array}$ & $\begin{array}{l}\text { Veterinary Clinical Diagnostics (2.5), Veterinary Microbiology (3.0), Veterinary Immunology (2.0), } \\
\text { Veterinary Pharmacology (3.0), Animal Pathophysiology (2.0), Animal Pathological Anatomy (2.0), } \\
\text { Veterinary Internal Medicine (2.5), Veterinary Obstetrics (2.5), Veterinary Infectious Diseases (3.0), } \\
\text { Veterinary Surgery (3.0), Veterinary Parasitology (2.5), Animal Food Hygiene (2.0), Chinese Trational } \\
\text { Veterinary Medicine (2.5) }\end{array}$ \\
\hline Professional elective courses & $\begin{array}{l}\text { Visual Foxpro Programming (2.5), General Animal Husbandry (1.5), Cell Biology (1.5), Molecular } \\
\text { Biology (1.5), Animal Ethology (1.5), Pharmaceutical Botany (1.5), Biostatistics (1.5), Livestock } \\
\text { Environmental Health Science (1.5), Animal Toxicology (1.5), Animal Microecology (1.5), Livestock } \\
\text { Economics (1.5), Experimental Design (1.5), Economic Animal Diseases (1.5), Animal Autopsy } \\
\text { Technology (1.5), Pharmaceutics of Traditional Chinese Medicine (1.5), Veterinary Biologicals (1.5), } \\
\text { Small Animal Diseases (1.5), Animal Hygiene Laws (1.5), Epizootiology (1.5), Zoonosis (1.5) }\end{array}$ \\
\hline Compulsory practical courses & $\begin{array}{l}\text { Veterinary Clinical Practice (4.0), Graduation Project (15.0), B. A Thesis Defense (1.0), Zoology } \\
\text { Practice (0.5), Veterinary Pharmacology Practice (1.0), Veterinary Infectious Diseases Practice (1.0), } \\
\text { Animal Food Hygiene Practice (1.0), Chinese Trational Veterinary Medicine Practice (0.5), Science } \\
\text { Research Training (2.0), Military Training and Theory (2.0), Test for Body Condition (2.0), } \\
\text { Enrollment Education (0.5), Graduation Education (0.5) }\end{array}$ \\
\hline
\end{tabular}

curriculum practice, and textbooks. The syllabus also contains important criteria for the evaluation of student and teacher (Warman, 2015). The examination outline of the national standard veterinarian qualification examination was issued in 2009 according to the administrative measures for practicing veterinarians. The examination outline contains the basic requirements of the national standard veterinarian qualification examination, and it provides a standard for exam setters and examinees. In order to satisfy the requirements of the veterinarian qualification examination, the syllabus of the VCD course should be subject to change. Our suggestions are as follows. Firstly, the syllabus of the VCD course should include sample examination questions about the national standard veterinarian qualification examination, which will motivate students; secondly, the credit hours of practical teaching in the VCD course should be changed from 10 credit hours to 20 credit hours; thirdly, the placement of the practical teaching should be extended to local farms, pet hospitals, and other teaching practice bases (May \& Head, 2010); finally, typical clinical cases that reflect multi-course crossovers should be added to the syllabus of the VCD course.

\subsection{Textbook for the VCD Course}

Textbooks are an important tool for learning of students (Khalil et al., 2010). At present, the national standard veterinarian qualification examination not only includes basic theoretical knowledge and clinical practice, but also involves in epidemiology, diagnosis, and treatment of the emerging diseases. Given the above-mentioned problems, the textbook of the VCD course should be updated based on the examination outline of the national standard veterinarian qualification examination. Firstly, the corresponding chapter in the VCD textbook should include the exams each year of the national standard veterinarian qualification examination. Secondly, the typical cases about the major animal diseases, specific species, and emerging diseases should be added to the textbook of the VCD course. Thirdly, as the concern of the small animal diseases increases, the small animal diseases which frequently occurred in China should be added to the textbook of the VCD course. Finally, the theoretical contents of the VCD course should be explained as deeply as possible using a clinical case, which will help students to understand these abstract theory and concepts. 


\subsection{Examination and Evaluation of the VCD Course}

Assessment is a powerful learning tool that can enhance learning and education. The process of student assessment should align with curricular goals and educational objectives (Fuentealba, 2011; Beran et al., 2012). At present, examination is still used to evaluate whether students have mastered the basic knowledge and practical skills of the VCD course. Meanwhile, examination of the VCD course can also motivate students to learn. Compared with the traditional exam, the national standard veterinarian qualification examination pays more attention to the application of basic knowledge, and clinical practical skills. It is suggested that the examination of the VCD course should be revised according to the exam types of the national standard veterinarian qualification examination. Firstly, the VCD course exam should be consisted of a theoretical knowledge examination and a clinical practice skills test, in which the theoretical knowledge examination accounts for $60 \%$ and the clinical practice skills test accounts for $40 \%$. Secondly, analysis of the clinical cases should be added to the theoretical knowledge examination for evaluation of the application of basic knowledge. Finally, the test of the clinical practice should be carried out in local farms and pet hospitals.

\section{Conclusion}

In this paper, we provide some suggestions about the teaching of the VCD course in the HBAU based on the national standard veterinarian qualification examination in China. Although the limited suggestions about the veterinary medicine course are described in this paper, it is necessary to remind that people who engage in veterinaryassociated teaching should pay attention to the national standard veterinarian qualification examination. We believe that the national standard veterinarian qualification examination will dramatically improve levels of the veterinary education in China.

\section{Acknowledgements}

This work is supported by the Teaching reform of Colleges and Universities in Heilongjiang Province (Grant No. JG2014010924), and the Teaching Supervisory Committee of Animal Production, Vocational and Technical Colleges, Ministry of Education of the People's Republic of China (Grant No. DJZW09019).

\section{References}

Beran, T. N., Donnon, T., \& Hecker, K. (2012). A Review of Student Evaluation of Teaching: Applications to Veterinary Medical Education. Journal of Veterinary Medical Education, 39, 71-78. http://dx.doi.org/10.3138/jvme.0311.037R

Fuentealba, C. (2011). The Role of Assessment in the Student Learning Process. Journal of Veterinary Medical Education, 38, 157-162. http://dx.doi.org/10.3138/jvme.38.2.157

Khalil, M. K., Mansour, M. M., \& Wilhite, D. R. (2010). Evaluation of Cognitive Loads Imposed by Traditional Paper-Based and Innovative Computer-Based Instructional Strategies. Journal of Veterinary Medical Education, 37, $353-357$. http://dx.doi.org/10.3138/jvme.37.4.353

Li, J., Guo, D., Zhou, D., \& Wu, X. (2011). Teaching Veterinary Internal Medicine in China. Journal of Veterinary Medical Education, 38, 194-198. http://dx.doi.org/10.3138/jvme.38.2.194

May, S. A., \& Head, S. D. (2010). Assessment of Technical Skills: Best Practices. Journal of Veterinary Medical Education, 37, 258-265. http://dx.doi.org/10.3138/jvme.37.3.258

Sun, D. B., \& Wu, R. (2009). Some Thoughts on Curriculum Reform of Veterinary Clinical and Diagnostic Sciences. Chinese Animal Husbandry Feed Science, 30, 149-150.

Wang, M. (2013). Sino-U.S. Joint Doctor of Veterinary Medicine (DVM) Training Program Writes New Chapter in Sino-U.S. Veterinary Education Collaboration. Journal World Education, 324, 57-64.

Warman, S. M. (2015). Challenges and Issues in the Evaluation of Teaching Quality: How Does it Affect Teachers’ Professional Practice? A UK Perspective. Journal of Veterinary Medical Education, 28, 1-7. http://dx.doi.org/10.3138/jvme.0914-096R1

Wen, X. T. (2010). The Certified Veterinarian Qualification Examination of China and Challenges of Veterinary Medicine Education of University in China. China Poultry, 32, 9-10.

Wu, H., \& Weng, C. P. (2009). The Certified Veterinarian and Certified Veterinarian System. Chinese Journal Veterinary Drug, 10, 29-33.

You, H., Yuan, L. L., Hong, G., Pan, P., \& Ren, H. (2010). Establishment and Prospect of Certified Veterinarian Qualification Examination System. Chinese Animal Husbandry Veterinary Medical, 42, 1-3. 